\title{
NOVÉ ARCHEOMETALURGICKÉ NÁLEZY Z AREÁLU KLEMENTINA V PRAZE
}

\author{
JAN HAVRDA - JAN ZAVŘEL
}

\begin{abstract}
Abstrakt: Při záchranných archeologických výzkumech na území pražské předlokační aglomerace jsou ze situací datovaných do 11. až 13. století stále ve větši míre ziskávány nálezy dokládající výrobu a zpracování neželezných kovỉ. V roce 2017 byl v nevelké zjišstovaci sondě na katastru Starého Města, v areálu pražského Klementina, získán dalši soubor archeometalurgických nálezů souvisejících s neželeznou metalurgii. SEM-EDS analýzy vybraných vzorků doložily na lokalitě specializovanou výrobní činnost, konkrétně výrobu cínového bronzu.
\end{abstract}

Klíčová slova: archeometalurgie - SEM-EDS analýza - výroba bronzu-Praha-12. století.

\section{New archaeometallurgical finds from Klementinum, Prague}

Abstract: Rescue archaeological research carried out in the territory of a pre-location agglomeration in Prague and contexts dated to the 11th-13th centuries have been yielding an increasing number of finds confirming the production and processing of non-ferrous metals. In 2017, a relatively small test pit in the cadastral zone of the Old Town, within the Klementinum complex, brought to light another series of archaeometallurgical finds associated with non-ferrous metallurgy. SEM-EDS analyses of selected samples confirmed specialized production activity on the site - the production of pewter bronze.

Key words: archaeometallurgy - SEM-EDS analysis - bronze production - Prague - 12th century.

\section{1 Úvod}

V posledních letech se rozšiřuje pramenná základna týkající se výroby a zpracování neželezných kovů v Praze v průběhu raného středověku. Doklady této specializované výrobní činnosti jsou známy např́íklad z vyšehradské akropole (Zavřel-Varadzin 2015, 391) a vyšehradského podhradí (Ettler et al. 2015; Wallisová 2006, 75), z centrální i jižní části Malé Strany (ZavřelČiháková-Ježek v tisku; Havrda-Tryml 2013, 125; Zavřel 2013, 219) nebo z Křemencovy ulice na Novém Městě (Vyšohlíd 2018, 32). Z katastru Starého Města jsou známé doklady zpracování neželezných kovů hlavně v jeho západní části, ze širšího okolí Klementina (Havrda-Zavřel 2009). Novými archeometalurgickými nálezy z tohoto území se zabývá i předkládaný text.

\section{Lokalizace výzkumu - rok 2017}

Klementinum, rozsáhlý areál na Starém Městě pražském vymezený ulicemi Seminářskou, Karlovou, Křížovnickou, Platnéřskou a na východě Mariánským náměstím (obr. 1), dnes sídlo Národní knihovny, leží na exponovaném místě pražské středověké aglomerace. Místo bylo kontinuálně osídleno nejpozději od 11. století. Předtím, ve druhé polovině 9 . a v první polovině 10. století sloužilo jako pohřební areál (Havrda-Žd'árská 2017). Osídlení 11. až první třetiny 13. století reprezentují četné archeologicky doložené sídlištní a výrobní objekty. První písemné zmínky o lokalitě se týkají až dominikánského kláštera. Bratři kazatelé sem přišli patrně již ve 30. letech 13. století. Klášter sv. Klimenta, archeologicky objevený v roce 2014, zaujímal takřka celou jižní polovinu areálu dnešního sídla Národní knihovny (Havrda-Kovář-Žd’árská 2017). ${ }^{1}$

Zjištovací archeologický výzkum provedený zde roku 2017 byl součástí předprojektových prací realizovaných před zahájením plánované 3. etapy revitalizace Klementina. Kromě sondy s archeometalurgickými nálezy (sonda S06) situované v hale služeb (obr. 2), která se nalézá na hlavním nádvoří areálu, byly při výzkumu v roce 2017 položeny čtyři sondy na hospodářském dvoře (Havrda-Rück1 2019).

1 Celý komplex Klementina je částečně archeologicky prozkoumán (přehledně Havrda 2017, 150; přehled výzkumů viz Havrda-Kovář-Žd'árská 2017, 14). 


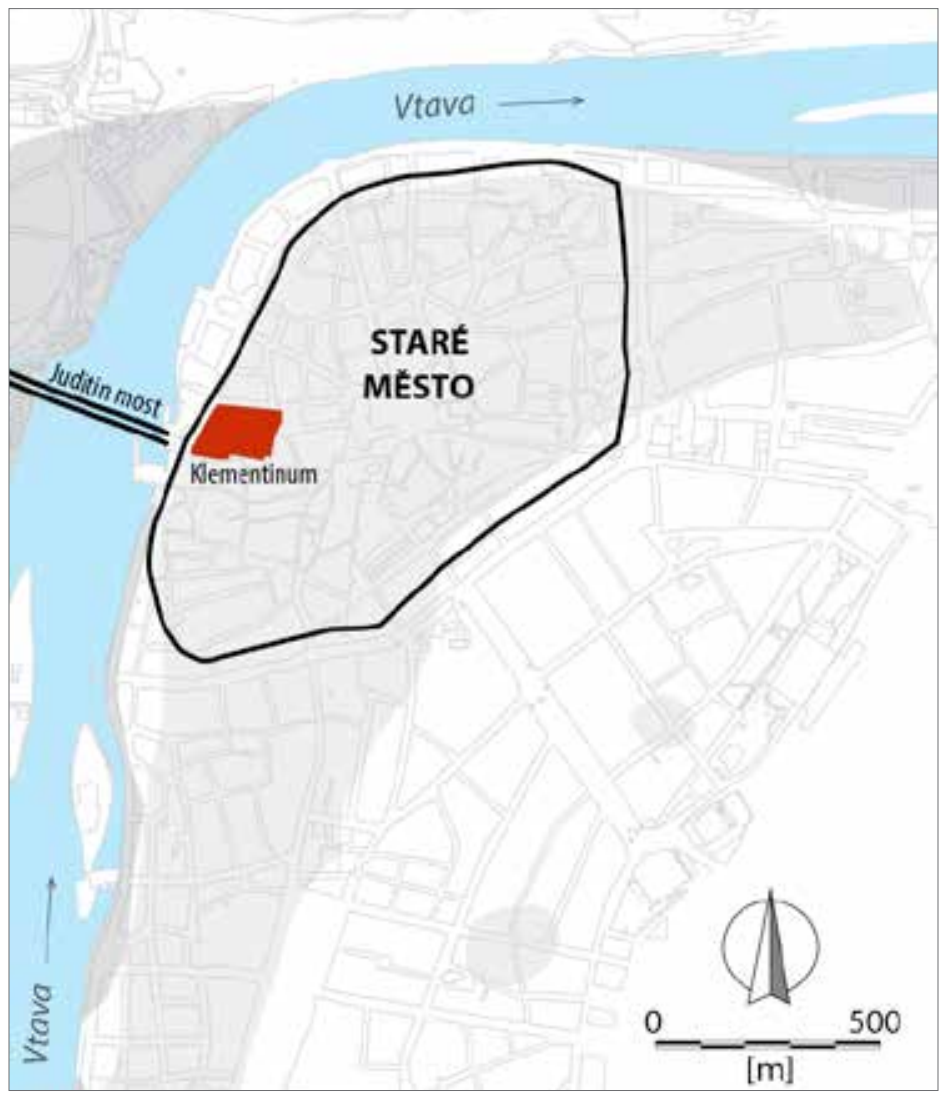

Obr. 1. Staré Město pražské chráněné hradbou dostavěnou v polovině 13. století. Červeně - areál Klementina, světle šedě - osídlení ve 12. až první polovině 13. století. Autorka S. Babušková.

Abb. 1. Von der Mitte des 13. Jhdts. fertiggestellten Stadtmauer geschützte Prager Altstadt. Rot - Areal des Clementinums, hellgrau - Besiedelung im 12. bis erste Hälfte 13. Jhdt. Erstellt von $S$. Babušková.

\section{Terénní situace v místě sondy S06}

Sonda S06 byla realizována v severovýchodním rohu haly služeb (obr. 2). Stratigraficky nejstarším objektem, nesouvisejícím s prezentovanou problematikou, byl raně středověký hrob z 10. století (Havrda-Žd'árská 2017). Níže prezentované a analyzované archeometalurgické nálezy pocházejí z výplně zahloubeného objektu (výkop V46) s rovným dnem a náznakem schodištových stupňů $v$ jeho jihozápadní části. Doložené zahloubení činilo $55 \mathrm{~cm}$, předpokládané 80 až $110 \mathrm{~cm}$ (obr. 3, 4), neúplná délka pak minimálně $2,9 \mathrm{~m}$. Tvar a velikost objektu, který předběžně interpretujeme jako část dřevohliněného domu se vstupní šíjí, nebylo možné určit, nebot' jeho rozměry přesahovaly plochu sondy. Horizontálně uložené vrstvy ve výplni vypovídají o jeho postupném zaplňování. Zánik objektu je možné na základě fragmentů keramiky (nádoby s archaicky zduřelým okrajem) datovat do druhé poloviny 11. až první poloviny 12 století (obr. 3; $5: 46,48,50,51)$. Už z nejstarší vrstvy u dna pocházejí hrudky a úkapky o vysoké hustotě pokryté modrozelenými sekundárními minerály mědi.

Do této vrstvy zasahoval mírně zahloubený objekt (výkop V44: hloubka $30 \mathrm{~cm}$, jeden rozměr min. $70 \mathrm{~cm}$ ), jehož dno tvořily vypálené kameny (břidlice, dolerit) o velikosti $5-10 \mathrm{~cm}$. 


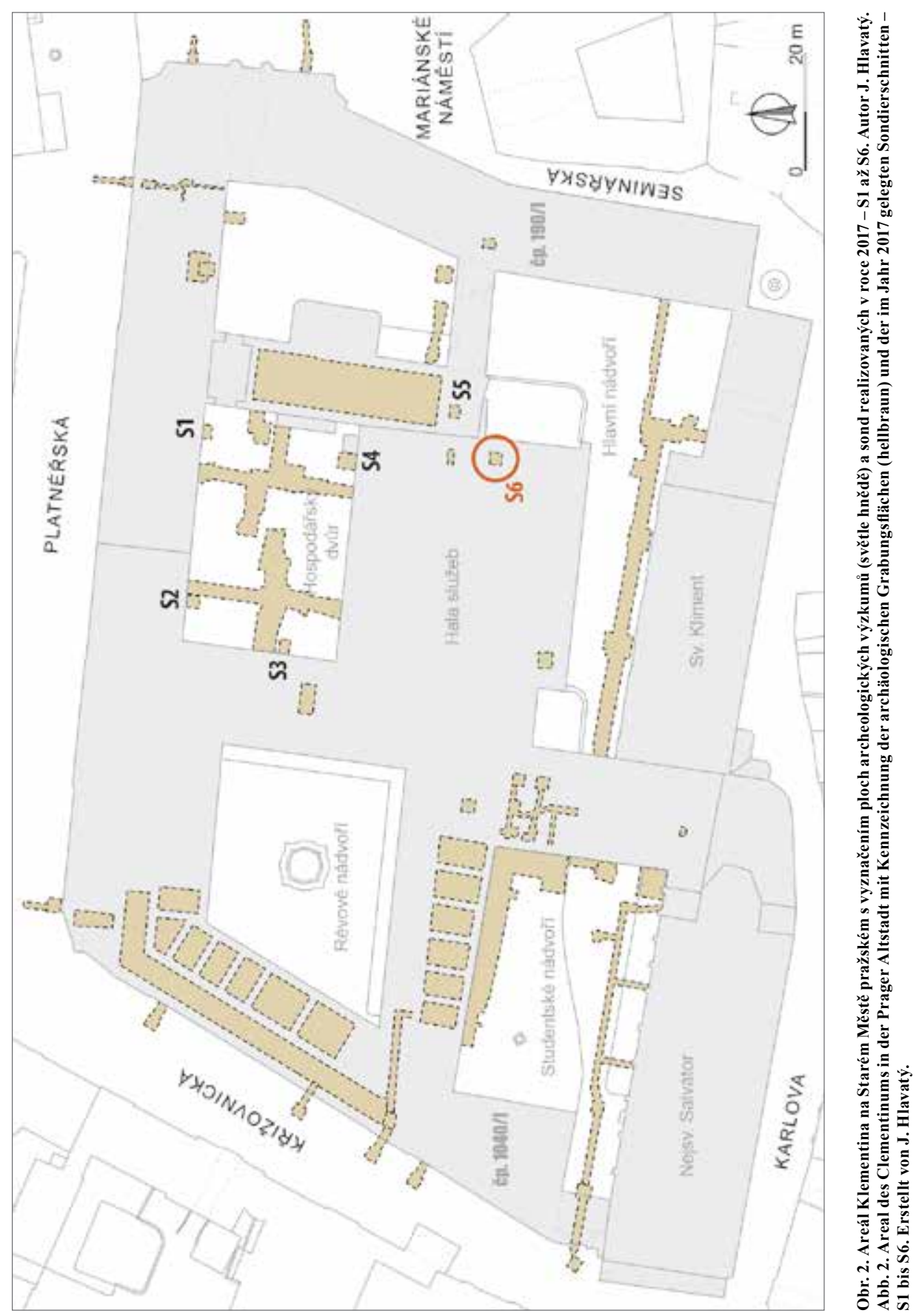



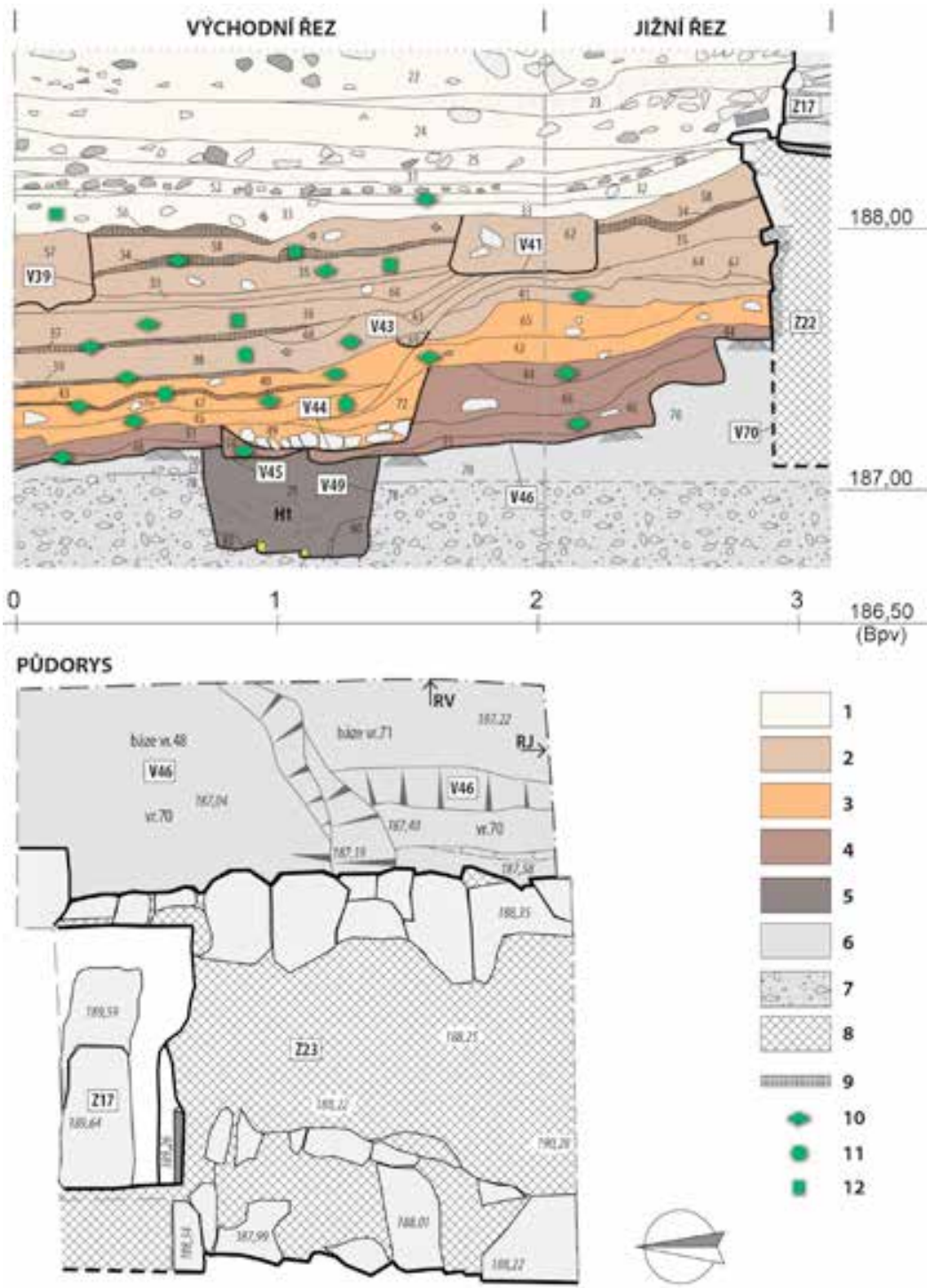

Obr. 3. Areál Klementina, sonda S06 v severovýchodním rohu haly služeb. Nahoře - východní a část jižního řezu sondy; dole - půdorys. 1 - zvyšování terénu, vrstvy se stavebním odpadem (2. polovina 13. - 17. století), 2 - sídlištní situace (2. polovina 12. - 1. polovina 13. století), 3 - sídlištní situace s pyrotechnologickým objektem (12. století), 4 - sídlištní situace, spodní výpln̆ zahloubeného objektu V46 (2. polovina 11. - 1. polovina 12. století), 5 - raně středověký hrob (10. století), 6 - písčitohlinité fluviální sedimenty, 7 - štěrkové fluviální sedimenty, 8 - základové zdivo, stavba v areálu dominikánského kláštera (13. století), 9 - vrstvy s uhlíky, 10 - vrstvy s archeometalurgickými nálezy - výrobním odpadem (úkapky barevných kovů), 11 - vrstvy s archeometalurgickými nálezy - fragmenty výrobních zařízení (kusy vypálené hlíny se struskovitými povlaky a zelenými poprašky), 12 - vrstvy s archeometalurgickými nálezy (zlomky keramiky se struskovitými povlaky). Podle Havrda-Rückl 2019, 119, upraveno.

Abb. 3. Areal des Clementinums, Sondierschnitt S06 in der nordöstlichen Ecke der Dienstleistungshalle. Oben - östlicher und Teil des südlichen Sondierschnitts; unten - Grundriss. 1 - Geländeerhöhung, Schichten mit Bauabfall (2. Hälfte 13. 17. Jhdt.), 2 - Siedlungssituation (2. Hälfte 12. - 1. Hälfte 13. Jhdt.), 3 - Siedlungssituation mit pyrotechnologischem Objekt (12. Jhdt.), 4 - Siedlungssituation, untere Verfüllung des eingetieften Objektes V46 (2. Hälfte 11. - 1. Hälfte 12. Jhdt.), 5 frühmittelalterliches Grab (10. Jhdt.), 6 - fluviale Sand-Lehm-Sedimente, 7 - fluviale Geröllsedimente, 8 - Fundamentmauerwerk, Gebäude im Areal des Dominikanerklosters (13. Jhdt.), 9 - holzkohlehaltige Schichten, 10 - Schichten mit archäometallurgischen Funden - Produktionsabfall (Buntmetallgusstropfen), 11 - Schichten mit archäometallurgischen Funden Produktionsanlagenfragmente (gebrannte Lehmbrocken mit schlackigen Überzügen und grünem Beschlag), 12 - Schichten mit archäometallurgischen Funden (Keramikfunde mit Schlackenüberzügen). Nach Havrda-Rückl 2019, 119, bearbeitet. 


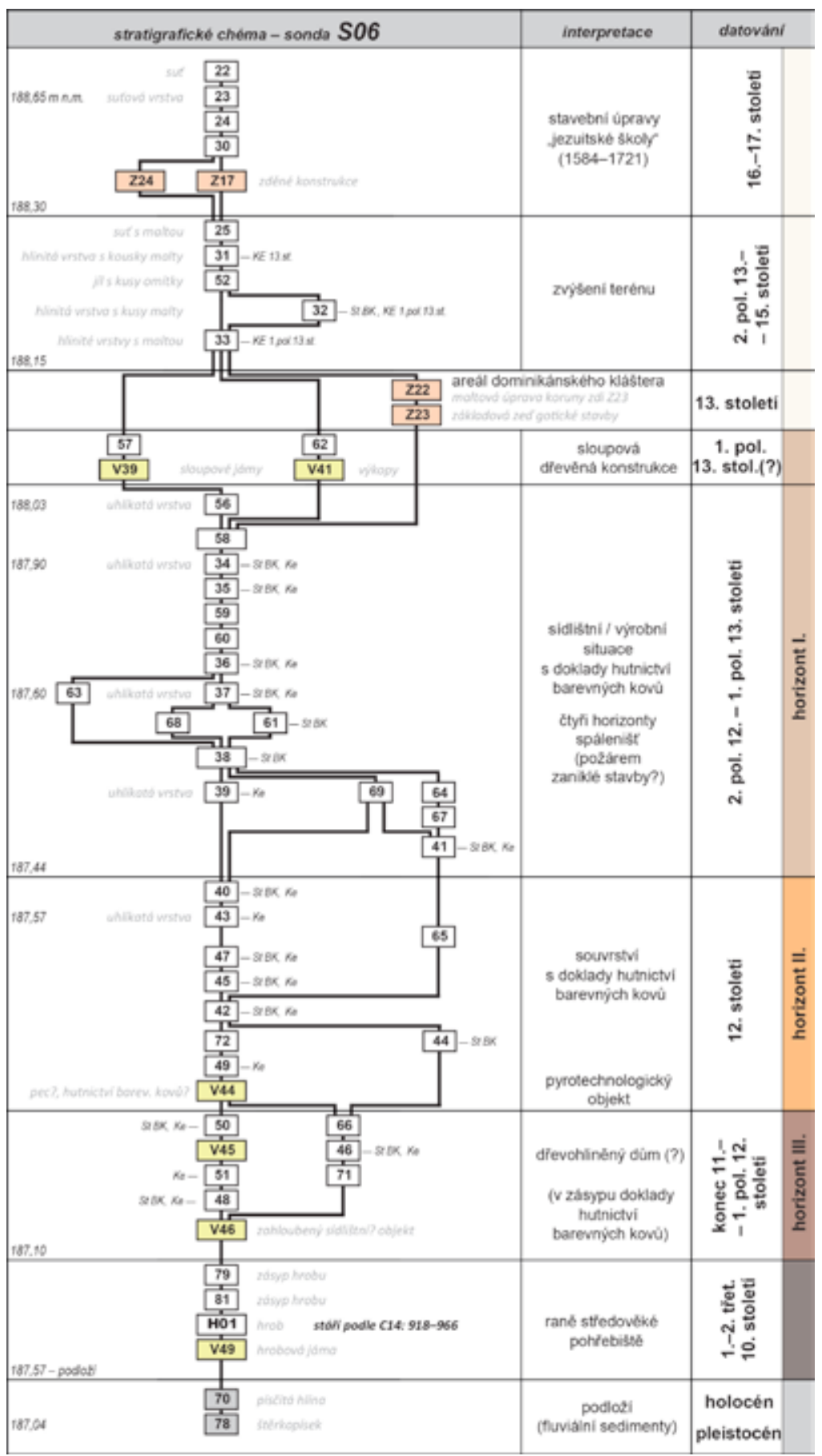

Obr. 4. Vývojový diagram - stratigrafické schéma sondy S06. StBK - archeometalurgické nálezy (struska, úkapky apod.), Ke - keramika, V - výkop (objekt), Z - zděná konstrukce. Podle Havrda-Rückl 2019, př́loha III, upraveno.

Abb. 4. Entwicklungsdiagramm - stratigrafisches Schema von Sondierschnitt S06. StBK - archäometallurgische Funde (Schlacke, Gusstropfen usw.), Ke - Keramik, V - Aushub (Objekt), Z - Wandkonstruktion. Nach Havrda-Rückl 2019, Anhang III, bearbeitet. 
V jeho výplni se vyskytovala mazanice a hrudka neželezného kovu. V tomto objektu a ve vrstvách, které ho překrývaly, byla nalezena keramika z okruhu tenkostěnných nádob se zduřelým okrajem řazených v rámci pražské sekvence středověké keramiky do 12 . století (obr. 3; 5:42, 43, $45,49)$.

Nad tímto objektem bylo v ploše $1,5 \mathrm{~m}^{2}$ dokumentováno ca $0,7 \mathrm{~m}$ mocné horizontální souvrství se čtyřmi polohami uhlíků s popelem a častým výskytem dalších archeometalurgických nálezů: střepů běžné keramiky se struskovitými povlaky, kusy šedočerné vypálené a natavené hlíny, kovových hrudek s povlaky zvětralin mědi a struskami. Souvrství datuje keramika s klasicky zduřelým okrajem do druhé poloviny 12 . až první třetiny 13. století (obr. 3; 5:35). Další vývoj místa je již spjat s výstavbou kamenných objektů v areálu dominikánského kláštera, při které zanikly všechny starší výrobní i sídlištní objekty (Havrda-Rück1 2019, 49-53).

\section{Popis vzorků a výsledky analýz}

V referované sondě S06 bylo získáno 103 kusů archeometalurgických nálezů o celkové hmotnosti $950 \mathrm{~g}$. Kromě výrobního odpadu se zde vyskytl i kovový šrot v podobě drátků a plíškủ. Obdobný charakter měly i některé nálezy v sondě $\mathrm{S} 04 \mathrm{v}$ jihovýchodním rohu hospodářského dvora vzdálené $20 \mathrm{~m}$ od sondy S06 (obr. 2).

Archeometalurgické nálezy byly na základě charakteru rozčleněny do pěti kategorií, vybrané charakteristické exempláře pak analyzovány metodou SEM-EDS ${ }^{2} \mathrm{v}$ laboratoři Geologického ústavu Akademie věd ČR, v. v. i., v Rozvojové ulici č. 269 Praze 6 - Lysolajích na elektronovém mikroskopu Tescan Vega 3 s detektorem Bruker XFlash 5010 za účasti analytičky Mgr. Š. Kř́ižové a RNDr. J. Zavřela.

\subsection{Zlomky běžné keramiky se struskovitými povlaky}

Soubor obsahoval celkem pět zlomků běžné raně středověké keramiky druhotně využitých při metalurgických operacích (obr. 6). Jejich velikost obvykle nepřesahovala několik $\mathrm{cm}^{2}$, pouze zlomek S06-36-16 byl rozměrnější $($ ca $75 \times 50 \mathrm{~mm}$ ). Síla střepů se pohybovala od 3 do $12 \mathrm{~mm}$. Všechny zlomky pocházely z nezdobených těl nádob, u jednoho z nich byly dochovány i části dna nádoby (S06-36-16). Tř́i střepy nahnědle šedé barvy (S06-34b, S06-35a S06-35b) obsahovaly na vnitřním povrchu různobarevné sklovité struskovité povlaky (tmavě červené, hnědé až šedé) a ojedinělé kulovité útvary (globulky) o průměru do $2 \mathrm{~mm}$, zbarvené zelenými povlaky a obsahující sekundární sloučeniny mědi. Textura povlaků byla značně různorodá, s nepravidelnou pórovitostí a členitým povrchem. Další fragment (S06-33) z větší silnostěnné šedohnědé hrncovité nádoby $\mathrm{s}$ hrubším ostřivem pokrývala šedá až šedohnědá tavenina místy se světle šedobílým povlakem, vzácně se šedými sférulkami kovového vzhledu. Tloušt'ka struskovitého povlaku se pohybovala od 1 do $2 \mathrm{~mm}$. Největší střep (S06-36-16) pochází z běžné hrncovité nádoby se dnem s průměrem ca $70 \mathrm{~mm}$. Oproti ostatním nálezům nemá struska sklovitý charakter. Na vnitřní, mírně žárem postižené stěně i na dně nádoby ulpěly nepravidelné, až $3 \mathrm{~mm}$ mocné šedočerné nálepy na povrchu značně členité taveniny pokryté povlakem zelených sekundárních minerálů mědi. Z uvedené skupiny byly blíže analyzovány dva vzorky.

Vzorek S06-35a

Střep je na vnitřní straně pokryt nesouvislými struskovitými porézními povlaky šedé, tmavě hnědočervené až světle zelenohnědé barvy, místy se skelným leskem. Ojediněle jsou př́ítomny kulovité útvary (globulky) o průměru do $2 \mathrm{~mm}$ pokryté modrozelenými sekundárními minerály mědi. Na vnější straně má střep místy žárem slabě zesklovatělý povrch (obr. 6).

Kompaktní partie strusky mají složení křemičito-olovnato-vápenato-hlinitého skla (tab. 1; analýzy č. 1 a 4). Rozpraskané povlaky v okolí sklovité strusky mají vyšší podíly křemíku,

2 SEM-EDS: skenovací elektronová mikroskopie s energiově disperzní analýzou. 

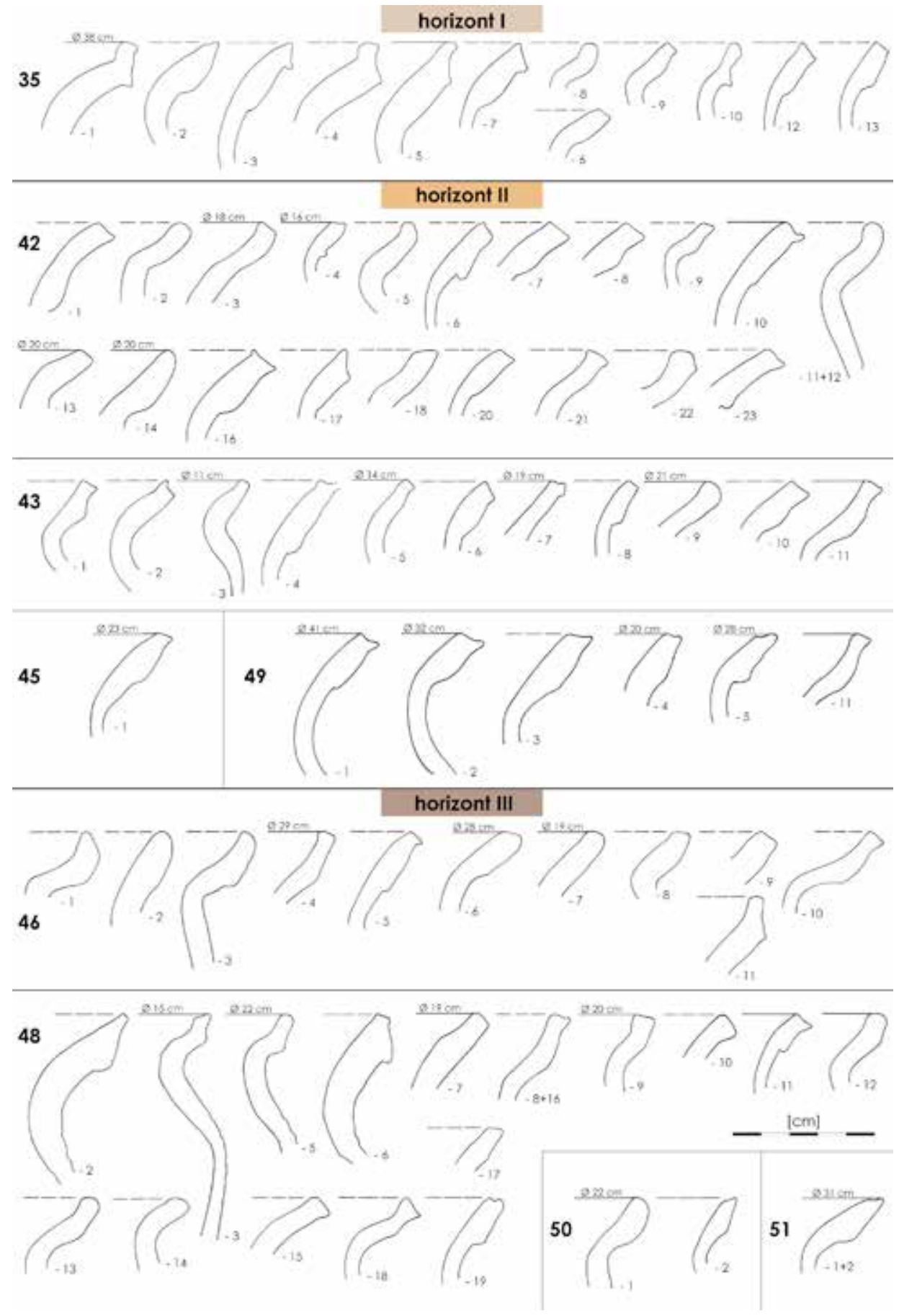

Obr. 5. Keramika ze sondy S06, profilace okrajů nádob - výběr. Kresba V. Čermák.

Abb. 5. Keramik aus Sondierschnitt S06, Profilierung der Gefäßränder - Auswahl. Zeichnung V. Čermák. 


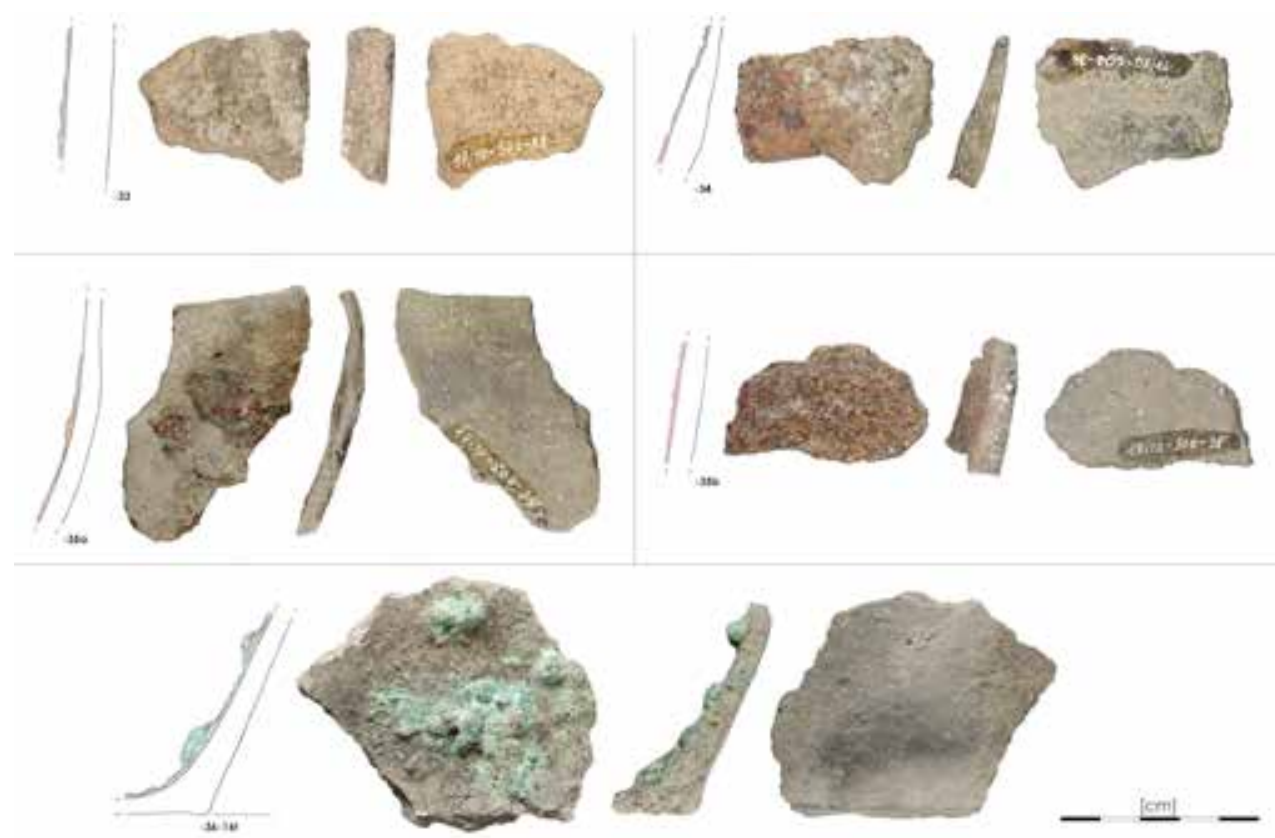

Obr. 6. Zlomky běžné středověké keramiky s červenými struskovitými povlaky a zelenými poprašky nalezené v sondě S06. Kresba V. Čermák, foto M. Kalíšek.

Abb. 6. In Sondierschnitt S06 gefundene Bruchstücke gängiger mittelalterlicher Keramik mit roten Schlackenüberzügen und grünem Beschlag. Zeichnung V. Čermák, Foto M. Kalíšek.

v př́ípadě analýzy č. 3 i železa, a obsahují i vedlejší až podružné koncentrace arsenu a cínu (tab. 1; anal. č. 2 a 3). Oblasti analýz č. 5 a 6 provedené v místě drobné vyvýšeniny (shluku?) jsou anomální podílem železa (kolem $40 \mathrm{hm} . \% \mathrm{Fe}_{2} \mathrm{O}_{3}$ ), olova $(20 \mathrm{hm} . \% \mathrm{PbO})$ i vápníku a křemíku. Struskovité povlaky na povrchu střepu mají nehomogenní vzhled i chemické složení.

\section{Vzorek S06-36-16}

Zlomek stěny a části dna nádoby je na vnitřní straně nesouvisle pokryt nepravidelnými hrudkami, povlaky a místy také drobnými globulkami modrozelené barvy. Na části střepu též ulpěl tenký šedočerný porézní povlak (obr. 6).

Tenký tmavý porézní povlak na části střepu vykazuje přítomnost oxidů železa s vedlejším podílem cínu a olova (tab. 1; anal. č. 7), který obsahuje shluky nabohacené olovnatou složkou (tab. 1; anal. č. 8). Dále byla analyzována sklovitá stěna jedné z rozlomených globulek (tab. 1; anal. č. 9, 10 a 11) i její vnitřek (anal. č. 12,13). Struska ze stěny globulky je bohatá $\mathrm{SiO}_{2}, \mathrm{FeO}$ a $\mathrm{Al}_{2} \mathrm{O}_{3}$ a obsahuje vedlejší podíl $\mathrm{Pb}$ i $\mathrm{Cu}$ (anal. č. 9, 10). Př́itomny jsou i světlé shluky tvořené patrně inkluzemi sulfidu mědi opět s vyšším zastoupením Fe (anal. č. 11). Vnitřek kulovitého útvaru tvoří oxid křemičitý (anal. č. 12) a povlaky mírně oxidované mědi (anal. č. 13). Zvětralinové povlaky reprezentují směsi sekundárních minerálů mědi a cínu (anal. č. 14 a 15).

Kromě hlavních neželezných prvků - mědi a cínu byly v povlacích analyzovaného střepu místy zaznamenány i koncentrace dalších rudních prvků - olova a arsenu. 


\begin{tabular}{|c|c|c|c|c|c|c|c|c|c|c|c|c|c|c|c|c|}
\hline Spectrum & $\mathrm{O}$ & $\mathrm{Cl}$ & $\mathrm{S}$ & $\mathrm{Na}$ & $\mathrm{Mg}$ & $\mathrm{Al}$ & $\mathrm{Si}$ & $\mathrm{P}$ & $\mathrm{K}$ & $\mathrm{Ca}$ & $\mathrm{Ti}$ & $\mathrm{Fe}$ & $\mathrm{Cu}$ & $\mathrm{As}$ & $\mathrm{Sn}$ & $\mathrm{Pb}$ \\
\hline 1 & 33,5 & - & - & 0,7 & 1,8 & 6,5 & 17,7 & - & 2 & 11,4 & 0,4 & 2,4 & 0,5 & - & - & 23,1 \\
\hline 2 & 44,7 & - & - & - & 0 & 7,1 & 24,1 & 0,2 & 2,2 & 5,9 & - & 2,9 & 0,7 & 2,4 & 2,6 & 7,3 \\
\hline 3 & 33,1 & - & - & - & - & 7,6 & 36,6 & 0,9 & 2,5 & 5,7 & 0,6 & 6,9 & 0,3 & 0,3 & - & 5,5 \\
\hline 4 & 26,1 & - & - & 0,6 & 0,7 & 4,2 & 18,5 & 0,2 & 3,5 & 7,6 & - & 2,3 & 1,4 & - & - & 35 \\
\hline 5 & 26,5 & - & - & - & 0,5 & 1,6 & 2,6 & 8,4 & 0,4 & 8 & - & 30,4 & 4,2 & 1,1 & - & 16,4 \\
\hline 6 & 36,6 & - & - & - & 0,7 & 1,4 & 1,9 & 7,6 & 0,2 & 5,4 & - & 25,5 & 3,5 & - & - & 17,1 \\
\hline 7 & 34,2 & - & - & - & 0,7 & 2,6 & 1,2 & 1,4 & - & 0,7 & 0,4 & 51,2 & 0,7 & - & 5,1 & 1,7 \\
\hline 8 & 26,3 & - & - & - & 0,4 & 1,9 & 0,7 & 4,4 & - & 2,8 & 0,4 & 34 & 1,3 & 1,4 & 3,8 & 22,7 \\
\hline 9 & 44,5 & - & 0,6 & - & 0,6 & 5,6 & 11,1 & 0,7 & - & 0,9 & - & 19,7 & 5,4 & - & 7,6 & 3,3 \\
\hline 10 & 40,5 & - & - & - & 1 & 5,4 & 14,7 & 0,4 & 1,1 & 2,2 & - & 14,5 & 1,2 & - & 15,8 & 3,2 \\
\hline 11 & 14 & - & 16,4 & - & - & 0,7 & 1,8 & 0,4 & 0,3 & 0,6 & - & 9,8 & 52,2 & 0,4 & 3,2 & - \\
\hline 12 & 44,2 & - & - & - & - & 1 & 52,2 & - & - & - & - & 1,4 & 1,3 & - & - & - \\
\hline 13 & 7,4 & 0,5 & - & - & - & - & 0,9 & - & - & - & - & 0,5 & 90,6 & - & - & - \\
\hline 14 & 33,6 & 3,1 & - & - & - & 0,1 & 0,2 & 12,7 & 0,9 & 7,3 & - & 1,1 & 34,8 & - & 6,2 & - \\
\hline 15 & 19,2 & - & - & - & - & - & - & 1,2 & - & - & - & - & 3,9 & - & 68,7 & 7 \\
\hline
\end{tabular}

Tab. 1. Výsledky analýz prvkového složení vzorků střepů se struskovitými povlaky S06-35a (analýzy č. 1 až 6$)$ a S06-36-16 (analýzy č. 7 až 15); údaje v hm. \% normalizované na $100 \%$.

Tab. 1. Ergebnisse der Analyse der Elementenzusammensetzung der Proben von Scherben mit Schlackenüberzügen S06-35a (Analysen Nr. 1 bis 6) und S06-36-16 (Analysen Nr. 7 bis 15); Angaben in Masse-\% normalisiert auf $100 \%$.

\subsection{Kusy vypálené a natavené hlíny se struskovitými povlaky a zelenými poprašky}

Z osmi vrstev výplně objektu V44 pochází celkem 15 drobných kusů šedočerně redukčně i cihlově červeně oxidačně vypálené a částečně natavené slídnaté a mírně písčité hlíny se struskovitými povlaky o celkové hmotnosti $310 \mathrm{~g}$. Průměrná velikost nálezů nepravidelného tvaru činí $45 \times 30 \mathrm{~mm}$, pouze výjimečně byly nalezeny kusy o velikosti až $85 \times 45 \mathrm{~mm}$. Jejich tloušt'ka se pohybuje od 10 do $30 \mathrm{~mm}$. Nebyly zaznamenány žádné specifické morfologické stopy (otisky, žebra, otvory, výstupky apod.). Na všech fragmentech je část povrchu pokryta různobarevnými porézními sklovitými struskovitými hmotami (hnědočervenými, šedočernými, jasně červenými i bílošedými), často s povlaky sekundárních minerálů mědi. Detailně analyzován byl jediný nález tohoto typu.

Vzorek 2017/10-S06-50-2

Světle šedě (redukčně) až světle cihlově červeně (oxidačně) vypálená jemně slídnatá porézní hlína s negativy po vyhořelé rostlinné hmotě je na jedné straně pokryta výrazně rozbrázděným skelně až kovově lesklým struskovitým povlakem ocelově šedé až tmavě hnědočervené barvy (obr. 7). Na lomu je povlak výrazně porézní a místy obsahuje shluky či poprašky modrozelených sekundárních minerálů mědi. Ze strusky vystupuje ojedinělá polokulovitá sférulka o průměru $5 \mathrm{~mm}$ též pokrytá popraškem Cu sekundárních minerálů.

Jednotlivé analyzované části povrchu struskovitého povlaku mají variabilní chemismus a jsou složené z oxidů či uhličitanů (kuprit, malachit ad.), fosforečnanů (pseudomalachit?) a případně chloridů mědi (tab. 2; anal. č. 1,3), dále jsou př́tomny krystalky oxidu cínu - kasiteritu (tab. 2; anal. č. 2) a sklovitá křemičito-vápenato-hlinitá matrix s kolísavým zastoupením mědi, cínu a železa (tab. 2; anal. č. 4, 5). 


\begin{tabular}{|c|c|c|c|c|c|c|c|c|c|c|c|c|c|c|c|}
\hline Spectrum & $\mathrm{O}$ & $\mathrm{Mg}$ & $\mathrm{Al}$ & $\mathrm{Si}$ & $\mathrm{P}$ & $\mathrm{S}$ & $\mathrm{Cl}$ & $\mathrm{K}$ & $\mathrm{Ca}$ & $\mathrm{Ti}$ & $\mathrm{Mn}$ & $\mathrm{Fe}$ & $\mathrm{Cu}$ & $\mathrm{Sn}$ & $\mathrm{Pb}$ \\
\hline 1 & 32,8 & 0,3 & 0,6 & 2 & 8,9 & 1,3 & 1,6 & 0,3 & 3 & - & - & 0,6 & 48,6 & - & - \\
\hline 2 & 20,2 & - & 0,4 & - & 0,7 & - & - & - & - & - & - & 0,4 & 9,1 & 69,1 & - \\
\hline 3 & 8,4 & - & - & - & - & - & - & - & - & - & - & - & 91,6 & - & - \\
\hline 4 & 41,4 & 4,9 & 6,7 & 18,7 & 0,4 & - & - & 1,6 & 13 & 0,3 & 0,7 & 6,5 & 5,3 & - & 0,5 \\
\hline 5 & 35,4 & 3,1 & 4,3 & 12 & 0,3 & - & - & 1,4 & 7 & 0,5 & 0,6 & 9,4 & 4,9 & 20,7 & 0,4 \\
\hline
\end{tabular}

Tab. 2. Výsledky prvkové analýzy struskovitého povlaku vzorku natavené hlíny S06-50-2; údaje v hm.\% normalizované na $100 \%$.

Tab. 2. Ergebnnisse der Elementenanalyse des Schlackenüberzugs der Probe des geschmolzenen Lehms S06-50-2; Angaben in Masse- \% normalisiert auf $100 \%$.

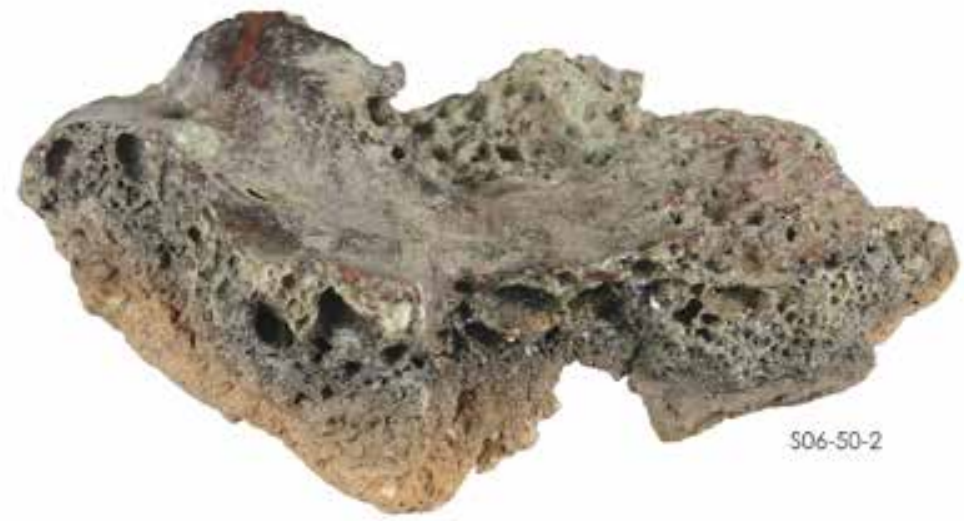

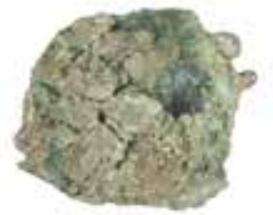

$\$ 06-46$

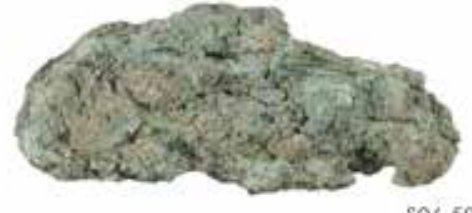

$\$ 06-50$
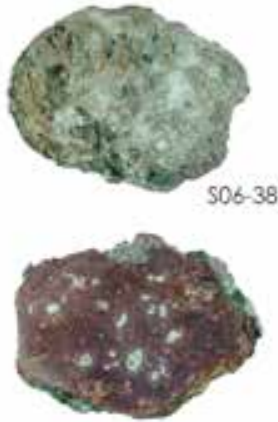

$5 \mathrm{~cm}$

0
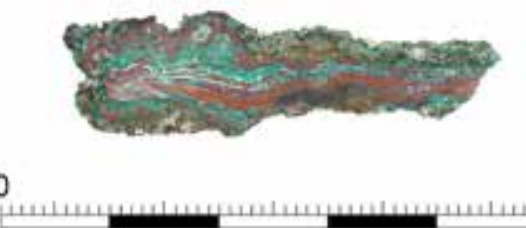

Obr. 7. Vybrané analyzované archeometalurgické nálezy: fragment stěny pece (S06-50-2), úkapky se zelenými poprašky na povrchu (S06-46 a S06-50) a struska (S06-38). Dole nábrusy úkapků a strusky. Foto M. Kalíšek, grafická úprava S. Babušková.

Abb. 7. Ausgewählte analysierte archäometallurgische Funde: Fragment einer Ofenwand (S06-50-2), Gusstropfen mit grünem Beschlag auf der Oberfläche (S06-46 und S06-50) und Schlacke (S06-38). Unten Querschliffe von Gusstropfen und Schlacke. Foto M. Kalíšek, grafische Bearbeitung S. Babušková. 


\subsection{Kovové hrudky, úkapy}

Nepravidelné hrudky o vysoké hustotě, zpravidla pokryté modrozelenými zvětralinovými povlaky sekundárních minerálů mědi tvoří nejčetnější soubor archeometalurgických nálezů (celkem 80 kusů o celkové hmotnosti 398 g). Většina nálezů má kulovitý, plochý či protáhlý tvar, někdy s výrazně protaženým koncem (obr. 7). Část vzorků je kovového vzhledu, jiné vykazují nepravidelnou houbovitou jemně porézní texturu. Průměrná velikost slitků se pohybuje od 8 do $25 \mathrm{~mm}$, výjimečně až $40 \mathrm{~mm}$.

Jednotlivé slitky a hrudky byly uloženy ve všech vrstvách tvořících raně středověkou část nadloží sondy S06. Analýzy se uskutečnily na třech kovových hrudkách. Před analýzou došlo k rozříznutí hrudek pomocí diamantového kotouče, jejich zalití do pryskyřice a vyleštění (vytvoření nábrusu).

\section{Vzorek S06-046}

Nepravidelná protáhlá hrudka o vyšší objemové hmotnosti je tvořena tmavě červenými a modrozelenými zvětralinovými kůrami a kovem světle zlatavé barvy, který je výrazněji zastoupený jen v části nábrusu (obr. 7). V elektronovém mikroskopu je v režimu zpět odražených elektronů patrné vícefázové složení kovu tvořené tmavou základní hmotou (tab. 3, anal. č. 1), sítovitou strukturou světle šedé barvy (tab. 3, anal. č. 2) a poměrně hojnými bělavými svítivými inkluzemi (tab. 3, anal. č. 3).

\section{Vzorek S06-50}

Plochá protáhlá hrudka kapkovitého tvaru o vyšší hustotě je tvořena jako v př́ípadě vzorku S06-46 modrozelenými a tmavě červenými zvětralinovými kůrami, které pokrývají kov zlatavé barvy (obr. 7). V elektronovém mikroskopu lze opět pozorovat vícefázový charakter kovu. $\mathrm{Na}$ základě analýz je možné shluk označit za slitinu cínu a mědi tvořenou dvěma fázemi (tab. 3; anal. č. 4 a 5) s př́íměsí olova (anal. č. 6).

\begin{tabular}{|c|c|c|c|c|}
\hline Spectrum & $\mathrm{O}$ & $\mathrm{Cu}$ & $\mathrm{Sn}$ & $\mathrm{Pb}$ \\
\hline 1 & - & 84,9 & 15,1 & - \\
\hline 2 & - & 67,8 & 32,2 & - \\
\hline 3 & 3,4 & 4,6 & - & 92,1 \\
\hline 4 & - & 84,5 & 15,5 & - \\
\hline 5 & - & 67,0 & 33,0 & 89,5 \\
\hline 6 & 4,2 & 6,4 & - & - \\
\hline
\end{tabular}

Tab. 3. Výsledky analýz nábrusu vzorků S06-46 (analýzy č. 1 až 3) a S06-50 (analýzy č. 4 až 6) v místě různých fází kovových shlukủ zlatavé barvy; údaje v hm. \% normalizované na $100 \%$.

Tab. 3. Ergebnisse der Analysen der Proben S06-46 (Analysen Nr. 1 bis 3) und S06-50 (Analysen Nr. 4 bis 6) in verschiedenen Phasen goldfarbener Metallagglomerate; Angaben in Masse-\% normalisiert auf $100 \%$.

\subsection{Strusky}

V sondě S06 bylo nalezeno několik desítek drobných strusek. Vyznačují se nepravidelným tvarem a lesklým hnědým, jasně červeným, šedým až hnědočerným zbarveným povrchem, na němž místy vystupují i zelené povlaky tvořené sekundárními minerály mědi. Strusky vykazují i proměnlivou porozitu a hustotu. Jejich průměr se pohybuje od 30 do $70 \mathrm{~mm}$. 


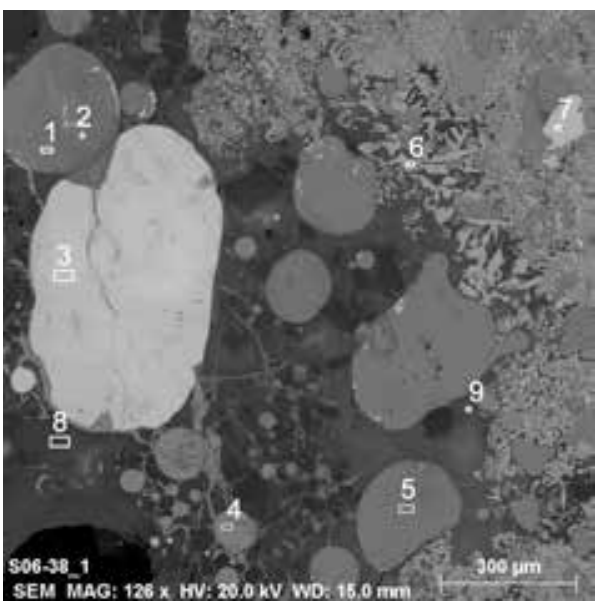

obr. 8

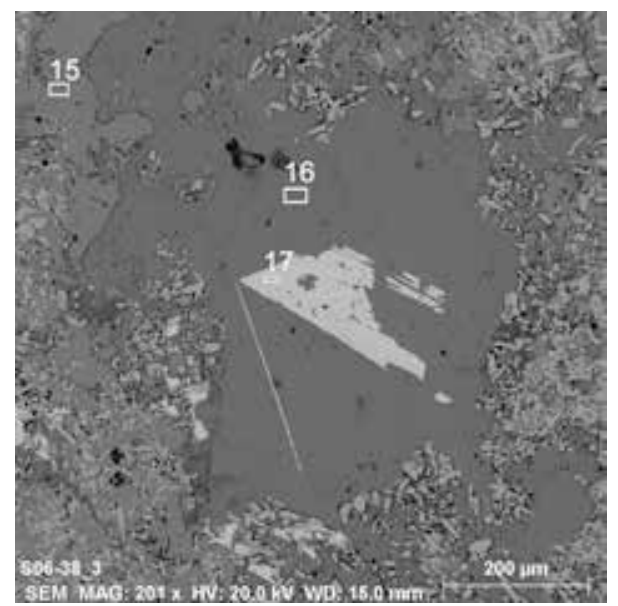

obr. 10

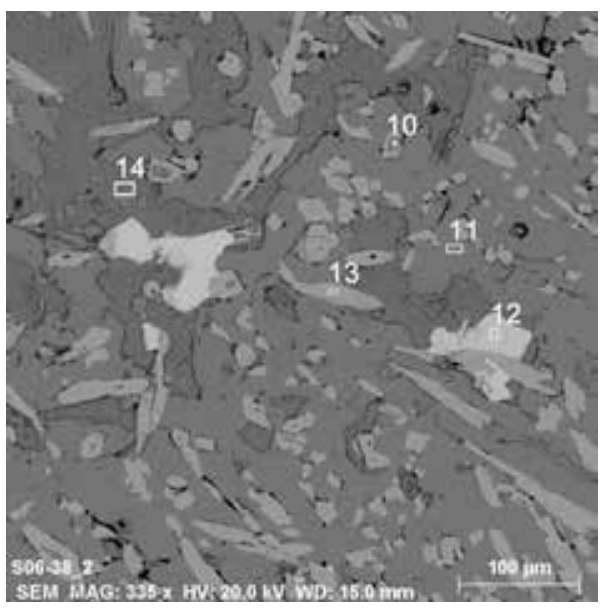

obr. 9

Obr. 8. Snímek elektronového mikroskopu - část nábrusu vzorku S06-38 s místy analyzovaných plošek a bodů č. 1 až 9 (režim BSE).

Abb. 8. Aufnahme eines Elektronenmikroskops - Teil des Querschliffs von Probe S06-38 mit analysierten Flächen und Punkten Nr. 1 bis 9 (BSE-Verfahren).

Obr. 9. Snímek elektronového mikroskopu - další část nábrusu vzorku S06-38 s místy analyzovaných plošek a bodů č. 10 až 14 (režim BSE).

Abb. 9. Aufnahme eines Elektronenmikroskops - weitere Querschliffe von Probe S06-38 mit analysierten Flächen und Punkten Nr. 10 bis 14 (BSE-Verfahren).

Obr. 10. Snímek elektronového mikroskopu - další část nábrusu vzorku S06-38 s místy analyzovaných plošek č. 15 až 17 (režim BSE).

Abb. 10. Aufnahme eines Elektronenmikroskops - ein weiterer Teil des Querschliffs von Probe S06-38 mit analysierten Flächen Nr. 15 bis 17 (BSE-Verfahren).

\section{Vzorek $S 06-38$}

Hrudka o vyšší hustotě je pokryta směsí modrozelených a modrých sekundárních minerálů mědi. Na řezu jsou zřetelné shluky a drobné inkluze kovu měděné barvy v nehomogenní tmavě červené matrix složené ze shluků sklovité fáze, malachitu a dalších makroskopicky neidentifikovatelných složek (obr. 7 až 10).

Analýzy potvrdily velkou rozmanitost vnitřní skladby zkoumaného vzorku. Jeho hlavní masu tvoř́i kuprit $\left(\mathrm{Cu}_{2} \mathrm{O}\right.$, tab. 4; anal. č. 10 [v dutině krystalu kasiteritu], 11 a 15), atacamit $\left(\mathrm{Cu}_{2}[\mathrm{OH}] \mathrm{Cl}\right.$, tab. 4; anal. č. 14, 16), sklovitá fáze křemičito-hlinitá se sumou alkálií kolem 10 hm.\% (tab. 4; anal. č. 8, 9) a několik generací krystalů kasiteritu (tab. 4; anal. č. 6, 13). Dále byly zjištěny nodule mědi, částečně zoxidované (tab. 4; anal. č. 4) nebo parciálně přeměněné na atacamit (tab. 4; anal. č. 1 a 5), i nodule olova se zvětralinami anglesitu (tab. 4; anal. č. 3) a samostatné krystalky anglesitu $\left(\mathrm{PbSO}_{4}\right.$, tab. 4 ; anal. č. 17). 


\begin{tabular}{|c|c|c|c|c|c|c|c|c|c|c|c|c|c|c|}
\hline Spectrum & $\mathrm{O}$ & $\mathrm{S}$ & $\mathrm{Cl}$ & $\mathrm{Cu}$ & $\mathrm{Sn}$ & $\mathrm{Pb}$ & $\mathrm{SiO}_{2}$ & $\mathrm{TiO}_{2}$ & $\mathrm{Al}_{2} \mathrm{O}_{3}$ & $\mathrm{MgO}$ & $\mathrm{CaO}$ & $\mathrm{Fe}_{2} \mathrm{O}_{3}$ & $\mathrm{Na}_{2} \mathrm{O}$ & $\mathrm{K}_{2} \mathrm{O}$ \\
\hline 1 & 13,8 & - & 28,0 & 58,2 & - & - & - & - & - & - & - & - & - & - \\
\hline 2 & 18,8 & 9,0 & 2,2 & 10,9 & - & 59,1 & - & - & - & - & - & - & - & - \\
\hline 3 & 34,8 & 11,0 & - & - & - & 54,2 & - & - & - & - & - & - & - & - \\
\hline 4 & 9,7 & - & 0,7 & 89,5 & - & - & - & - & - & - & - & - & - & - \\
\hline 5 & 12,1 & - & 29,6 & 58,4 & - & - & - & - & - & - & - & - & - & - \\
\hline 6 & 20,7 & - & - & - & 79,3 & - & - & - & - & - & - & - & - & - \\
\hline 8 & - & - & - & 1,8 & - & - & 51,9 & 0,7 & 23,4 & 3,4 & 2,4 & 6,5 & 3,9 & 3,7 \\
\hline 9 & - & - & - & 8,6 & - & - & 53,3 & - & 15,8 & 1,3 & 1,2 & 2,0 & 4,3 & 6,9 \\
\hline 10 & 9,6 & - & - & 90,4 & - & - & - & - & - & - & - & - & - & - \\
\hline 11 & 9,4 & - & - & 90,6 & - & - & - & - & - & - & - & - & - & - \\
\hline 12 & 19,5 & 9,1 & - & 1,7 & - & 69,7 & - & - & - & - & - & - & - & - \\
\hline 13 & 19,0 & - & - & 2,5 & 78,4 & - & 0,1 & - & - & - & - & - & - & - \\
\hline 14 & 2,9 & - & 31,9 & 65,2 & - & - & - & - & - & - & - & - & - & - \\
\hline 15 & 9,8 & - & - & 90,2 & - & - & - & - & - & - & - & - & - & - \\
\hline 16 & 6,6 & - & 31,1 & 62,3 & - & - & - & - & - & - & - & - & - & - \\
\hline 17 & 19,9 & 10,4 & - & 2,0 & - & 67,7 & - & - & - & - & - & - & - & - \\
\hline
\end{tabular}

Tab. 4. Výsledky analýz nábrusu vzorku S06-38; údaje v hm. \% normalizované na $100 \%$.

Tab. 4. Ergebnisse der Analysen des Querschliffs von Probe S06-38; Angaben in Masse- \% normalisiert auf $100 \%$.

\subsection{Předměty a jejich zlomky z neželezných kovio}

Výkop zachytil sedm nálezů z neželezných kovů o celkové hmotnosti $17 \mathrm{~g}$. Zastoupeny byly dva ústřižky zohýbaných tenkých plíšků o velikosti $10 \times 30$ a $15 \times 45 \mathrm{~mm}$ a tři drátky dlouhé 30 až $60 \mathrm{~mm}$ (obr. 11). Tento kovový šrot patrně představoval surovinu připravenou k sekundárnímu zpracování. Kromě toho byly nalezeny i dva snad ztrátové předměty: nýtek o průměru hlavičky $20 \mathrm{~mm}$ a délce trnu $7 \mathrm{~mm}$ a jeden kroužek o průměru 3,8 a síle drátu $4 \mathrm{~mm}$. Nálezy z této skupiny dosud nebyly analyzovány.

\section{Diskuse}

Raně středověkou metalurgii v prostoru sondy S06 dokládá pět skupin nálezů - střepy běžné keramiky se struskovitými povlaky, fragmenty pecních stěn, kovové hrudky, strusky a kovový šrot.

Nejpočetnější skupinu reprezentují nepravidelné hrudky či úkapy neželezných kovů o vysoké hustotě, které mají povrch pokrytý výraznými zvětralinovými kůrami vytvořenými v rámci postdepozičních procesů. Obě analyzované hrudky S06-46 a S06-50 z této skupiny lze charakterizovat jako dvousložkové slitiny mědi a cínu s příměsí olova - cínové bronzy. Strukturou i chemismem odpovídají starším nálezům z jiných částí areálu Klementina.

Využívání pecí při metalurgických operacích dosvědčují zlomky natavených a vypálených hlín často pokrytých struskovitými povlaky. Analýzy nataveného povrchu zlomku pece S06-50-2 doložily jeho variabilní chemismus a přítomnost sekundárních minerálů mědi, krystalků kasiteritu i sklovité křemičito-vápenato-hlinité matrix s kolísavým zastoupením mědi, cínu a železa. Složení povlaku odpovídá reakci bronzové strusky s hliněnou stěnou či nístějí pece. 


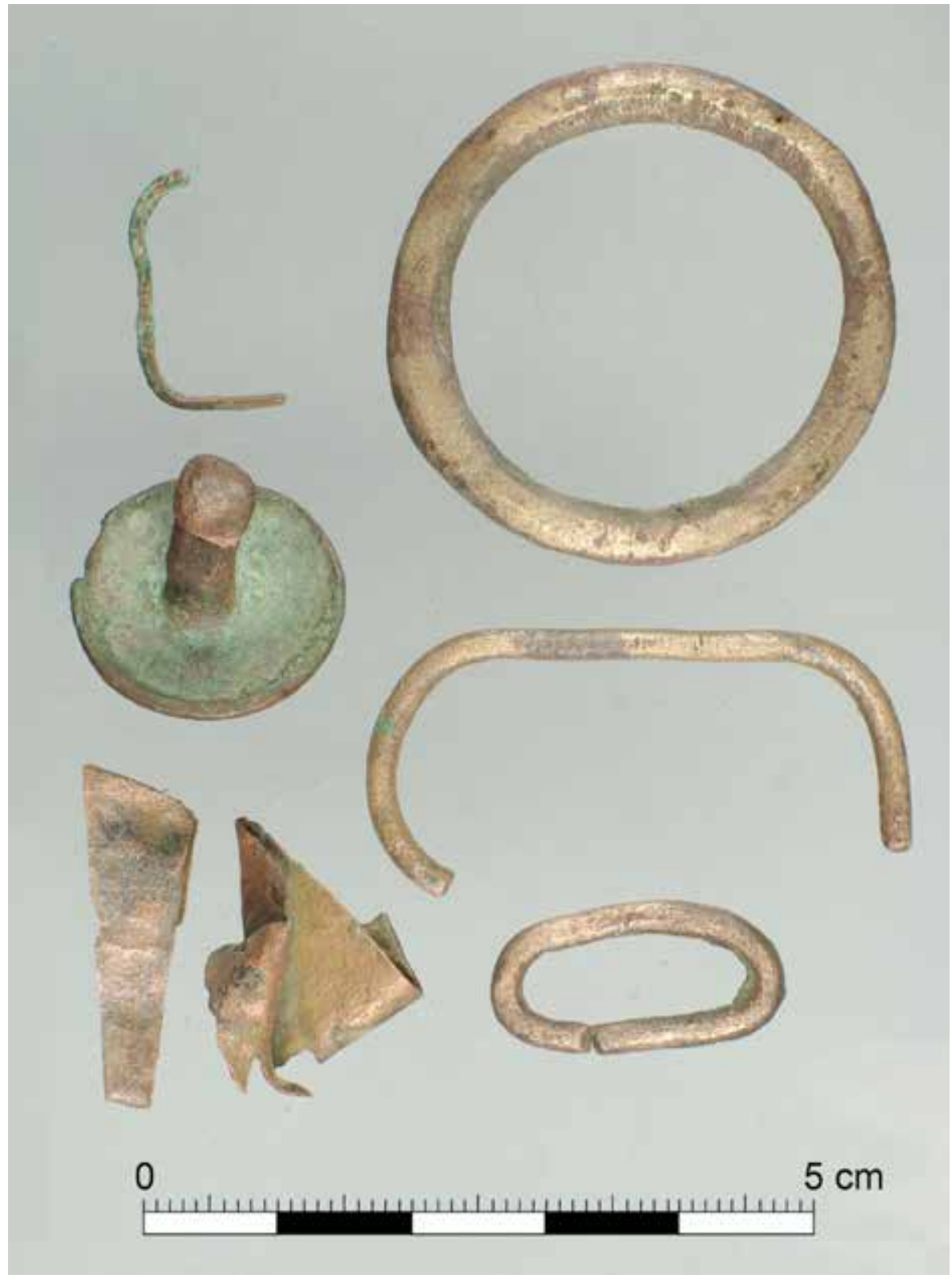

Obr. 11. Drobné artefakty z neželezných kovů - předměty a jejich zlomky ze sond S6 a S4. Foto M. Kalíšek.

Abb. 11. Kleine Artefakte aus Nichteisenmetallen - Gegenstände und ihre Bruchstücke aus den Sondierschnitten S6 und S4. Foto M. Kalíšek.

Za mimořádné archeometalurgické nálezy lze označit nepravidelné hrudky o vyšší hustotě, které jsme zatím řadili do skupiny strusek. Analyzovaná struskovitá hmota S06-38 odpovídá složením mnoha dalším vzorkům $\mathrm{z}$ Klementina zkoumaným v dřívějších etapách a opět jednoznačně souvisí s výrobou cínového bronzu. Heterogenní stavba těchto hmot s často poměrně ostře ohraničenými oblastmi lišícími se velikostí a množstvím krystalů oxidu cíničitého, 
zastoupením sklovité fáze, kovových globulek nebo kupritu, resp. dalších sekundárních minerálů mědi a olova, je pro tento typ zdejších nálezů typická. Jisté analogie se zatím podařilo najít jen v zahraniční literatuře, ale týkají se výhradně analýz archeometalurgických vzorků z různých období prehistorie (např. Figueiredo et al. 2010), výjimečně i z experimentálních taveb bronzu napodobujících pravěké výrobní postupy (Lackinger et al. 2001). Vzorky z Klementina nejlépe odpovídají materiálům vzniklým při společném redukčním hutnění rozdrcených a $\mathrm{s}$ dřevěným uhlím smíchaných rud mědi a cínu $\mathrm{v}$ jednoduchých malých píckách zapuštěných pod úroveň terénu, prŕípadně cementaci mědi materiálem bohatým na cín (ruda Sn nebo kovový šrot $\mathrm{s}$ vysokým obsahem cínu). Vzniklé struskovité polotovary se značným podílem nodulí neželezných kovů a jejich slitin výrazně proměnlivého složení byly při dalším postupu výroby roztloukány, propírány a získané kovové perličky dále zpracovávány. Budoucí výzkumy snad pomohou zodpovědět otázku, zda tyto hrudky představují výrobní odpad nebo se jedná o polotovar určený k dalšímu zpracování.

Z technické keramiky se v sondě S06 vyskytly pouze zlomky běžné raně středověké keramiky sekundárně využité při neželezné metalurgii. V dosud blíže analyzovaných souborech obdobných, ale většinou starších nálezů z Vyšehradu (Varadzin-Zavřel 2015, 391 n) a Malé Strany (Zavřel-Čiháková-Ježek v tisku) výrazně převládaly střepy použité při rafinaci stř́ibra metodou kupelace. Cílovým produktem těchto metalurgických postupů byly koláčovité placičky stříbra zbavené většiny nežádoucích příměsí, které po utuhnutí kovu a jeho vyjmutí zanechaly ve struskovitém povlaku na vnitřní straně střepu typické kruhové či mírně eliptické negativy. Takovéto typy miskovitých metalurgických střepů jsme v prostoru sondy S06 nezaznamenali. Povlak na zlomku nádoby S06-35a dokládá práci s kostním popelem (koncentrace $\mathrm{Ca}, \mathrm{P}$ ), olovem, př́ipadně klejtem (obsahy $\mathrm{Pb}$ ) v rámci blíže neurčeného postupu (rafinaci?, testu?) při zpracování neželezných kovů nebo jejich slitin (vedlejší až podružné podíly $\mathrm{Cu}, \mathrm{Sb}, \mathrm{As}$ ). Další analyzovaný střep S06-36-16 sloužil k nějaké úpravě surovin souvisejících s výrobou cínového bronzu. Nelze vyloučit, že na jeho povrchu ulpěly pozůstatky zkoušky (průby) vypraženého kamínku (tj. hutnického poloproduktu tvořeného kyzy [sulfidy] $\mathrm{Fe}, \mathrm{Cu}$ a dalších prvků) na obsah zpracovávaných kovů. Úloha miskovitých střepů se stopami mědi, cínu či zinku, případně slitin těchto prvků na povrchu dosud není uspokojivě vysvětlena.

$\mathrm{Na}$ rozdíl od jiných zkoumaných míst $\mathrm{v}$ Klementinu se zde mezi archeometalurgickými pozůstatky nevyskytl další typ technické keramiky - tavicí kelímky (tyglíky). Nebyly nalezeny ani prubířské kameny, které se podařilo získat při výzkumech $\mathrm{v}$ jiných částech areálu bývalé jezuitské koleje. Poměrně nízké zastoupení zde měly i železářské strusky.

\section{Závěr}

Na základě plošně malého archeologického výzkumu, při kterém byla prozkoumána plocha o velikosti $1,5 \mathrm{~m}^{2}$, se podařilo získat množství drobných archeometalurgických nálezů. Jejich SEM-EDS analýzy dokládají práci se slitinami mědi - výrobu cínového bronzu v blíže tvarově neurčených pecích hliněné konstrukce a využití miskovitých zlomků běžné keramiky při této výrobě (testy surovin či poloproduktů?). Nálezy heterogenních struskovitých hmot s vysokým podílem kupritu, krystalků kasiteritu proměnlivého habitu, kovových nodulek $\mathrm{Cu}$, resp. $\mathrm{Cu}-\mathrm{Pb}$ a sklovité fáze mohou patrně indikovat společné redukční hutnění rud mědi a cínu, př́ípadně cementaci mědi materiálem bohatým na cín - rudou Sn nebo kovovým šrotem s vysokým obsahem tohoto kovu. Výzkumem se podařilo rozšiŕit plochu s výskytem raně středověkých archeometalurgických nálezů souvisejících s neželeznou metalurgií v prostoru pražské raně středověké předlokační aglomerace.

Příspěvek vznikl s podporou Grantové agentury ČR, projekt reg. č. 16-22207S. 


\section{Prameny a literatura}

ETTLER, V. et al., 2015: Ettler, V.-Johan, Z.-Zavřel, J.-Selmi-Wallisová, M.-Mihaljevič, M.-Šebek, O., Slag Remains from the Na Slupi Site (Prague, Czech Republic), Journal of Archaeological Science 53, 72-83. https://doi.org/10.1016/j.jas.2014.10.007

FIGUEIREDO, E. et al., 2010: Figueiredo, E.-Silva, R. J. C.-Senna-Martinez, J. C.-Araújo, M. F.-Fernandes, F. M. B.-Inês Vaz, J. L., Smelting and recycling evidences from the Late Bronze Age habitat site of Baiões (Viseu, Portugal), Journal of Archaeological Science 37, 1623-1634.

HAVRDA, J., 2017: Dominikánský klášter sv. Klimenta. In: Boháčová, I.-Podliska, J. a kol., Průvodce pražskou archeologií. Památky známé, neznámé i skryté, 150-153. Praha.

HAVRDA, J.-KOVÁŘ, M.-ŽĎÁRSKÁ, A., 2017: Dominikánský klášter sv. Klimenta v Praze na Starém Městě - St. Clement Dominican monastery in the Old Town of Prague, Staletá Praha 33, sv. 2, 2-71.

HAVRDA, J.-RÜCKL, Š., 2019: Nálezová zpráva. Zjištovací archeologický výzkum Praha 1 - Staré Město, Klementinum čp. 190/I a 1040/I, ppč. 80 a 82 (archeologické sondy na Hospodářském dvoře a jižně od něho v roce 2017), výzkum NPÚ, ÚOP v Praze č. 2017/10, č. j. 311/32896/2019, ulož. v dokumentaci archeologického odboru NPÚ, ÚOP v Praze.

HAVRDA, J.-TRYML, M., 2013: Nebovidy. Středověká osada v pražském podhradí - Nebovidy. Mediaeval settlement around Prague Castle. Praha.

HAVRDA, J.-ZAVŘEL, J., 2009: Pozůstatky raně středověkého metalurgického pracoviště v areálu Klementina na Starém Městě pražském - Remains of the early medieval metallurgical workshop in the area of Clementinum in the Old Town of Prague, Archaeologica Pragensia 19/2008, 333-357.

HAVRDA, J.-ŽĎÁRSKÁ, A., 2017: K pohřbívání v pravobřežní části pražské předlokační aglomerace v 9. a 10. století. Objev pohřebiště v areálu Klementina - Zum Begraben im rechtsufrigen Teil der Vorlokations-agglomeration Prags im 9. und 10. Jahrhundert. Das Gräberfeld im areal des Prager Klementinums, Staletá Praha 33, sv. 2, 94-134.

LACKINGER, A. et al., 2013: Copper + Tin + People: Public Co-Smelting Experimentation in Northwestern Iberia. Proceedings of the 7th UK Experimental Archaeology Conference Cardiff 2013, EXARC Journal 3.

VARADZIN, L.-ZAVŘEL, J., 2015: Pozůstatky raně středověké metalurgie stříbra, zlata a dalších neželezných kovů na Vyšehradské akropoli. In: Moucha, V.-Nechvátal, B.-Varadzin, L. et al., Vyšehrad. Knížecí a královská akropole, 391-419. Praha.

VYŠOHLÍD, M., 2018: Praha - Nové Město, Zaniklá ves Opatovice v Křemencově ulici na Novém Městě pražském. In: Archeologické výzkumy v Čechách 2017 (sborník referátů z informačního kolokvia). Zprávy České archeologické společnosti - Supplément 109, 32.

ZAVŘEL, J., 2013: Stopy neželezné metalurgie. In: Havrda, J.-Tryml, M., Nebovidy. Středověká osada v pražském podhradí, 219-22. Praha.

ZAVŘEL, J.-ČIHÁKOVÁ, J.-JEŽEK, M., v tisku: Domestic pottery sherds used in non-ferrous metalworking in medieval Prague. Archaeological and Anthropological Sciences.

\section{Zusammenfassung}

\section{Neue archäometallurgische Funde vom Areal des Clementinums in Prag}

In den letzten Jahren hat sich die Quellengrundlage für das frühe Mittelalter bezüglich der Herstellung und Bearbeitung von Nichteisenmetallen in Prag vergrößert. Im Jahr 2017 wurde bei einer kleinen Feststellungssondierungsgrabung im Areal des Clementinums in der Prager Altstadt ein interessanter Komplex archäometallurgischer Funde aus der Zeit der zweiten Hälfte des 11. bis zur ersten Hälfte des 13. Jahrhunderts entdeckt. Die Funde wurden ihrem Charakter nach in fünf Kategorien untergliedert: 1) Bruchstücke von gängiger Keramik mit Schlackenüberzügen, 2) Fragmente von Ofenwänden mit Schlackenüberzügen, 3) Metallklumpen, Gusstropfen und Ofensäue, 4) Schlacken, 5) Metallschrott (Gegenstände aus Nichteisenmetallen und ihre Bruchstücke). Eine Auswahl an charakteristischen Exemplaren wurde mit dem SEM-EDS-Verfahren analysiert.

Durch die Untersuchung wurde die Herstellung von Zinnbronze in von der Form her unbestimmten Lehmöfen und unter Verwendung von schüsselförmigen Bruchstücken gängiger 
Keramik bei der Herstellung (Rohstofftests oder Halbprodukte?) belegt. Funde von heterogenen schlackenartigen Massen mit hohem Anteil an Cuprit, Kassiteritkristallen von variablem Habitus, metallene CU-, bzw. CU-Pb-Klümpchen und Glasphase können offenbar eine gemeinsame Reduktionsverhüttung von Kupfer- und Zinnerzen, ggf. eine Zementation von Kupfer durch ein zinnreiches Material - Zinnerz oder Metallschrott mit hohem Gehalt dieses Metalls - indizieren.

Der vorliegende Beitrag entstand mit Unterstützung der Förderagentur der Tschechischen Republik, Projekt-Reg.-Nr. 16-22207S.

Mgr. Jan Havrda, Národní památkový ústav, územní odborné pracoviště v Praze, Na Perštýně 12, 11000 Praha 1, Česká republika, havrda.jan@npu.cz

RNDr. Jan Zavřel, M. J. Lermontova 11, 16000 Praha 6, Česká republika, zavreljan@centrum.cz 
